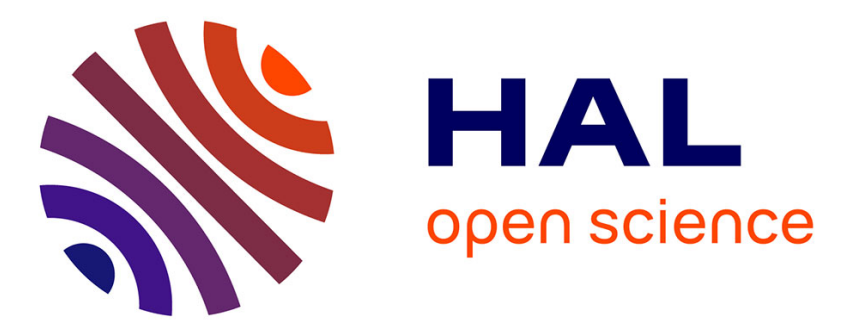

\title{
Foreign Exchange Reserve Management in the 19 th Century: The National Bank of Belgium in the 1850s Stefano Ugolini
}

\section{To cite this version:}

Stefano Ugolini. Foreign Exchange Reserve Management in the 19 th Century: The National Bank of Belgium in the 1850s. Anders Ögren, Lars Fredrik Øksendal. The Gold Standard Peripheries: Monetary Policy, Adjustment and Flexibility in a Global Setting, Palgrave Macmillan, 2012, 978-0230-36231-4. hal-01293720

\section{HAL Id: hal-01293720 \\ https://hal-univ-tlse2.archives-ouvertes.fr/hal-01293720}

Submitted on 25 Mar 2016

HAL is a multi-disciplinary open access archive for the deposit and dissemination of scientific research documents, whether they are published or not. The documents may come from teaching and research institutions in France or abroad, or from public or private research centers.
L'archive ouverte pluridisciplinaire HAL, est destinée au dépôt et à la diffusion de documents scientifiques de niveau recherche, publiés ou non, émanant des établissements d'enseignement et de recherche français ou étrangers, des laboratoires publics ou privés. 


\title{
Foreign Exchange Reserve Management in the $19^{\text {th }}$ Century: The National Bank of Belgium in the $1850 \mathrm{~s}^{1}$
}

\author{
Stefano Ugolini \\ Scuola Normale Superiore di Pisa \\ stefano.ugolini@sns.it
}

\begin{abstract}
:
As well as the current one, the wave of globalization culminated in 1913 was marked by increasing accumulation of foreign exchange reserves. But what did 'reserves' mean in the past, how were they managed, and how much relevant are the differences between then and now? This paper is the first attempt to investigate $19^{\text {th }}$-century reserve management from central banks' perspective. Building on a significant case study (the National Bank of Belgium, i.e. the 'inventor' of foreign exchange policy, in the 1850s), it shows that risk management practices in the past differed considerably from nowadays. The structure of the international monetary system allowed central banks to minimize financial risk, while poor institutional design enhanced operational risk: this is in stark contrast with the present situation, in which operational risk has been minimized and financial risk has considerably increased. Yet $19^{\text {th }}$-century reserve management was apparently not conducive to major losses for central banks, while the opposite seems to have been the case in the $21^{\text {st }}$ century.
\end{abstract}

JEL: E42, E58, G11, N23.

Keywords: Foreign exchange reserves, international monetary systems, central banking, risk management.

\footnotetext{
${ }^{1}$ The author would like to thank Anders Ögren and Lars Fredrik Øksendal for their kind invitation to contribute, as well as Olivier Accominotti and Clemens Jobst for their very useful comments on an earlier draft. Advice in archival research by Pierre de Longuemar, Arnold de Schepper, Geert Leloup, and Dorothea McEwan is gratefully acknowledged. The usual disclaimers apply.
} 


\section{Introduction}

One of the most interesting aspects of the monetary action of peripheral countries during the gold standard era consists of their widespread adoption of foreign exchange policies, which turned the international monetary system into a de facto gold-exchange standard by the end of the $19^{\text {th }}$ century. ${ }^{2}$ As much as the current one, the first wave of globalization was thus accompanied by increasing accumulation of foreign reserves. This striking parallelism is fascinating, and economists might be legitimately tempted to look for insights from the past. There are at least two dimensions along which such an exercise can be performed. One concerns the motives for accumulation and the relative role of reserve currencies in the structure of the international monetary system: for instance, which lessons for the dollar's current position might be drawn from sterling's past performance? These questions, which bear a lot of relevance from a macroeconomic viewpoint, have already started to be approached by the literature. ${ }^{3}$ An alternative dimension concerns the practicalities of the accumulation process: what were reserves made of in the $19^{\text {th }}$ century, how were they actually managed at the time, and do the differences between now and then have something to teach us? These questions, which are particularly interesting from a microeconomic viewpoint, have never been addressed up to now: as a matter of fact, very few elements about the practical aspects of foreign exchange policy have emerged so far. ${ }^{4}$ Given the relatively low level of disclosure associated with these activities, details remain largely unknown even for the case of today's central banks; concerning the past, most crucial elements are still buried in archives - if not lost forever.

This chapter is the first attempt to look specifically at foreign exchange reserve management practices in the $19^{\text {th }}$ century. It is based on fresh archival research covering a particularly relevant case study: the National Bank of Belgium (i.e. the first central bank to engage massively into foreign exchange policy) during its first years of operation (1851-3). Of course, the aim is not to provide an exhaustive description of $19^{\text {th }}$-century reserve management practices - still an impossible task given the current state of research. Rather, the idea is to provide a preliminary assessment of the complexity of foreign portfolio management in the past, its differences with today, and the implications of such differences.

\footnotetext{
${ }^{2}$ De Cecco, M. (1974)

${ }^{3}$ See Eichengreen, B. \& Flandreau, M. (2009) for a discussion.

${ }^{4}$ A number of details are dispersed across the single histories of each central bank, but no systematic account is available for the period before 1913. Jobst, C. (2007), Reis, J. (2007), and Øksendal, L. (2008) provide elements on reserve management practices in Austria-Hungary, Portugal, and Norway respectively; albeit from a different perspective, Flandreau, M. \& Gallice, F. (2005) give insights on the way peripheral European countries' deposits with international banks were managed. Eichengreen, B. \& Flandreau, M. (2009) and Accominotti, O. (2010) cover the interwar period.
} 
The remainder of the chapter is organized as follows. The first section provides the interpretative framework for this study and summarizes recent trends in reserve management practices. The second section introduces the structure of $19^{\text {th }}$-century international payments systems and financial intermediation. The third and fourth sections focus on the Belgian case study, looking at the management of financial and operational risk respectively. The chapter ends with conclusions.

\section{Foreign Exchange Reserve Management in the 21 ${ }^{\text {st }}$ Century: An Introduction}

Although a number of different reasons for holding reserves can be found, all of them ensue from the wish to sterilize some current or future capital movement. ${ }^{5}$ In order to be able to pursue this aim in a sustainable way, central banks have always oriented their foreign portfolio management towards the reconciliation of two potentially conflicting targets: liquidity (the ability to dismiss reserves easily at any moment) and profitability (the ability to receive an adequate remuneration for the capital allocated to reserves). If one is to study the dynamics of such portfolio choices, it is convenient to adopt the viewpoint of central bankers and look at them as risk management practices. Risk involved in foreign reserve management takes the form of financial and operational risk. On the one hand, the financial risk associated with a given security is defined as composed by credit risk (the risk that the payments linked to the security will be defaulted), market risk (the risk that the value of the security will decrease due to aggregate market factors), and liquidity risk (the risk that the security will not be exchangeable quickly enough to avoid a loss). On the other hand, the operational risk associated with a given transaction is defined as the risk of loss resulting from inadequate or failed internal processes. Throughout the chapter, this useful framework will be adopted in order to compare past and current practices.

Starting from the present, it must be acknowledged that details on nowadays' foreign reserve management do not abound. One of the most useful available sources consists of a 2007 survey conducted by the Bank for International Settlements. ${ }^{6}$ Concerning the management of financial risk, the report argues that a new trend has emerged since the 1980s. Before that decade, central banks used to hold reserves in highly-liquid and safe assets, such as gold, bank deposits, Treasury bills, and sovereign bonds. Concern about the social cost of dramatically increasing foreign reserves, however, has nurtured a more profit-oriented attitude

\footnotetext{
${ }^{5}$ For a taxonomy, see Borio, C. et al. (2008a), pp. 2-3.

${ }^{6}$ Borio, C. et al. (2008b)
} 
towards reserve management. This has also been encouraged by the idea that financial innovation had been enhancing the liquidity of riskier securities, thus transforming them into proper instruments for central bank investment. As a result, the list of asset classes included in official portfolios has expanded, to include instruments of much longer maturity than before such as agency paper, mortgage-backed securities, corporate debt, and even equities. ${ }^{7}$ This expansion has also produced changes in the management of operational risk. While decision about the 'philosophy' of investment has been left to top executives, practical management has progressively been split among a multitude of specialized agents, and sometimes even outsourced to external managers. This horizontal separation has been implemented with the aim of limiting opportunities for conflicts of interest, but also of shielding monetary authorities from criticism associated with specific choices. ${ }^{8}$

Nowadays' foreign reserve management differs from the $19^{\text {th }}$-century one from the viewpoint of both the instruments involved and the organization of operations. As suggested by the next section, this is tied to crucial dissimilarities in the structure of the international payments system and of international financial intermediation.

\section{Foreign Exchange Reserve Management in the $19^{\text {th }}$ Century: An Introduction}

At a time when most countries adhered to some kind of convertibility rule (gold, silver, or bimetallic standard), central banks were required to maintain their banknotes payable in bullion. In such a framework, it is impossible to qualify gold and silver holdings as 'foreign reserves' properly speaking: as a matter of fact, bullion used to be legal tender and could thus be employed in order to broaden or shrink the domestic monetary base. In what follows, therefore, gold and silver will not be considered as instruments for foreign reserve accumulation.

In the $19^{\text {th }}$ century, the term 'foreign exchange' was used as a synonym to the market price of a particular asset class: bills of exchange payable on a foreign place. ${ }^{9}$ Bills of exchange (or, as they later came to be known, acceptances) were negotiable promissory notes with multiple

\footnotetext{
${ }^{7}$ The 2008 shock seems to have reversed this trend. Pihlman, J. \& van der Hoorn, H. (2010) argue that since the burst of the crisis central banks have shown a markedly procyclical attitude in foreign reserve management. It is interesting to note that this massive flight to quality has also concerned bank deposits - traditionally considered as a low-, not a high-risk asset. This suggests that the architecture of the international banking system has grown much more unstable than it used to be.

${ }^{8}$ Of course, outsourcing reserve management to external managers is bound to constitute an additional source of procyclicality - as anecdotal evidence from the 2008 crisis seems to show.

${ }^{9}$ See e.g. Goschen, G. (1864).
} 
guarantees: bound to be paid at maturity by one person (the acceptor) who had agreed to certify the quality of the original debtor (the drawer), they were also secured by the signatures of all the people who had previously held and resold them (the endorsers). ${ }^{10}$ Due to their particular convenience in bridging the information asymmetries associated with overseas transactions, bills of exchange had become the staple instrument for international payments since the early modern age. Of course, the system was not fully exempt from abuses: for instance, the so-called 'cross-firing' (the mutual drawing and accepting of two bills of the same amount by two colluding agents) constituted a typical refinancing device that de facto annihilated the value of the guarantees. ${ }^{11}$ Moreover, multiple guarantees could also become a dangerous vehicle of contagion during crises. ${ }^{12}$ Yet despite these downsides, the system had nonetheless proved basically resilient to major shocks over the centuries. The primacy of bills as the most liquid asset class available to investors was definitively established in the $1850 \mathrm{~s}$, when a considerable expansion and deepening of the markets for these securities took place. This was tied to two interconnected phenomena: the spectacular growth in world trade and finance, and the general introduction of lending-of-last-resort facilities by central banks. ${ }^{13}$ As a result, acceptances became unrivalled as the most suitable instrument for the placement of foreign reserves. $^{14}$

Bills of exchange entered almost all kinds of portfolios, being bought (or 'discounted') by specialized money market funds (known as discount houses), by commercial banks, by private investors, etc. The most active players in the origination of bills, however, were concentrated in a specific segment of the banking sector: private investment banks known as merchant banks. Merchant banks were trading houses which had gradually specialized in finance. Owing to their original business activities, they had established those multinational networks of correspondents which constituted the necessary condition for performing accepting on a broad scale. ${ }^{15}$ Yet merchant banks did not only originate bills: they also performed a number of services for their customers (e.g. the encashment of coupons or of bills originated by other houses), took deposits, operated on the bullion market, and underwrote bonds and equities. Towards the end of the $19^{\text {th }}$ century, the successful model of

\footnotetext{
${ }^{10}$ Accominotti, O. (2011) provides a description of the system through which bills of exchange were originated, and stresses the similarities between accepting and modern credit default swaps.

${ }^{11}$ Courcelle-Seneuil, J.-G. (1857), pp. 169-72

12 Schnabel, I. \& Shin, H. (2004)

${ }^{13}$ Flandreau, M. \& Ugolini, S. (2011)

14 This does not mean that bills always were the only exchange-traded securities entering central banks' portfolios. For instance, the Bank of Norway used to keep a portion of its reserves in sovereign bonds: Øksendal, L. (2008).

${ }^{15}$ Chapman, S. (1984)
} 
merchant banking was increasingly imitated by multinational joint-stock banks - some of which (as e.g. Paribas: see below) were former merchant houses evolved into universal banks. Seconded by technological improvements (viz. the introduction of telegraphic transfers), these new intermediaries started to offer more competitive forms of deposits to their customers. Despite their inherently higher riskiness, ${ }^{16}$ these new types of claims would eventually outperform bills as the favourite instrument for the placement foreign reserves - albeit not before the interwar period. ${ }^{17}$ Because of the variety of services they offered to their customers, foreign merchant banks were by far the most convenient agents with which $19^{\text {th }}$ century central banks could interact in order to manage reserves. By contrast, relationships with other banks of issue were extremely rare: foreign reserves were almost never kept in the form of deposits with other monetary institutions. ${ }^{18}$ Contacts between central banks were generally scanty: some information was exchanged concerning very technical issues (e.g. counterfeiting or bookkeeping practices), ${ }^{19}$ but even direct transactions between monetary authorities (e.g. bullion swaps) were performed through the intermediation of merchant banks. ${ }^{20}$ As a matter of fact, foreign reserve management remained something to be fully undisclosed to those monetary authorities which would suffer from the pressure of reserve liquidations during crises.

\section{Financial Risk in $19^{\text {th }}$-Century Foreign Reserve Management: The Belgian Case}

Since the very beginning of its operations, the National Bank of Belgium (hereafter NBB) engaged heavily into foreign exchange policy. This depended on the need to reconcile a formal mandate to maintain convertibility with an informal one to stabilize domestic interest rates. In order to pursue these conflicting aims, the Bank started to perform open market operations on a massive scale, which resulted in the accumulation of huge foreign reserves. ${ }^{21}$

Both the NBB's primacy in foreign exchange policy and the breadth of its operations (covering up to six currencies at the time) make the Bank an ideal candidate for a case study on $19^{\text {th }}$-century foreign reserve management practices. To perform a detailed microeconomic

\footnotetext{
${ }^{16}$ Contrary to bills, deposits did not bear a multiple guarantee.

${ }^{17}$ Battilossi, S. (2000), Eichengreen, B. \& Flandreau, M. (2009)

${ }^{18}$ Exceptions did exist. For instance, the Bank of Japan used to keep a portion of its reserves deposited with the Bank of England: Suzuki, T. (1994). This kind of arrangement became much more popular in the interwar period: Eichengreen, B. \& Flandreau, M. (2009). Detailed information about today's situation was impossible to find.

${ }^{19}$ For the Belgian case, see e.g. PV CdA, $23^{\text {rd }}$ September $1850,4^{\text {th }}$ May and $12^{\text {th }}$ June $1858,29^{\text {th }}$ October 1859.

${ }^{20}$ Flandreau, M. (1997)

${ }^{21}$ Ugolini, S. (2011a)
} 
analysis, this chapter makes use of a high-frequency database covering the Bank's first three years of operation (January 1851 to December 1853). ${ }^{22}$

\section{Asset Class Composition}

In order to analyse the NBB's management of financial risk, the first step consists of investigating the asset class composition of the portfolio. Figure 1 shows that only two types of instruments were held by the Bank: bills of exchange payable abroad, and deposits with foreign banks. While deposits dominated in the very beginning (when the Bank's network was in its setting-up phase), their share shrank rapidly: in 1852-3, bills of exchange exceeded $85 \%$ of the total portfolio on average.

Figure 2 gives data in absolute numbers and provides details on bills and deposits held in each of the six currencies the Bank was dealing with. ${ }^{23}$ It is possible to see that, as a general rule, deposits only constituted a residual part of portfolio management operations: they typically remained close to zero, and tended to increase temporarily in periods when the Bank was diminishing its holdings in that given currency. ${ }^{24}$ On the whole, figure 2 testifies the role of the bill of exchange as the staple instrument of the NBB's foreign reserve management. ${ }^{25}$

\footnotetext{
${ }^{22}$ The database is the one gathered by Ugolini, S. (2011a), but is complemented here with additional evidence collected from archival sources. Although a number of elements concerning the NBB's foreign reserve management practices can be found in Kauch, P. (1950), no specific account of them existed to date.

${ }^{23}$ Note that the NBB used to keep deposits with only one bank for each currency area - viz. with its 'regular correspondents' (see below).

${ }^{24}$ This was tied to the NBB's preference for holding short-term bills of exchange, and for holding them until maturity. As the ordinary duration of these monetary instruments was ninety days, maintaining a stable bill portfolio meant that maturing securities had to be continuously replaced by newly-discounted ones. This was done through the intermediation of correspondents: as renewal took place almost immediately, the NBB's deposits with these banks tended to be close to zero. When the Bank wished to diminish its exposition to a given currency, though, a semi-active divestment strategy was generally preferred to an active one: instead of being sold on the open market, foreign bills were simply not replaced by new ones at maturity. Such a strategy implied that the encashment of maturing bills produced a temporary increase in deposits with correspondents, which would only be converted into other currencies in a second moment.

${ }^{25}$ However, figure 2 also shows that one remarkable exception to this rule did exist. Deposits with the Paris Rothschild house behaved differently: they averaged around $2 \mathrm{~m}$ francs in 1852-3, but not less than $5 \mathrm{~m}$ in $1851-$ constantly making for the overwhelming part of total foreign deposits. The exceptionality of the Rothschilds' case is discussed below.
} 
Figure 1: Composition of foreign reserves per asset class, 1851-3

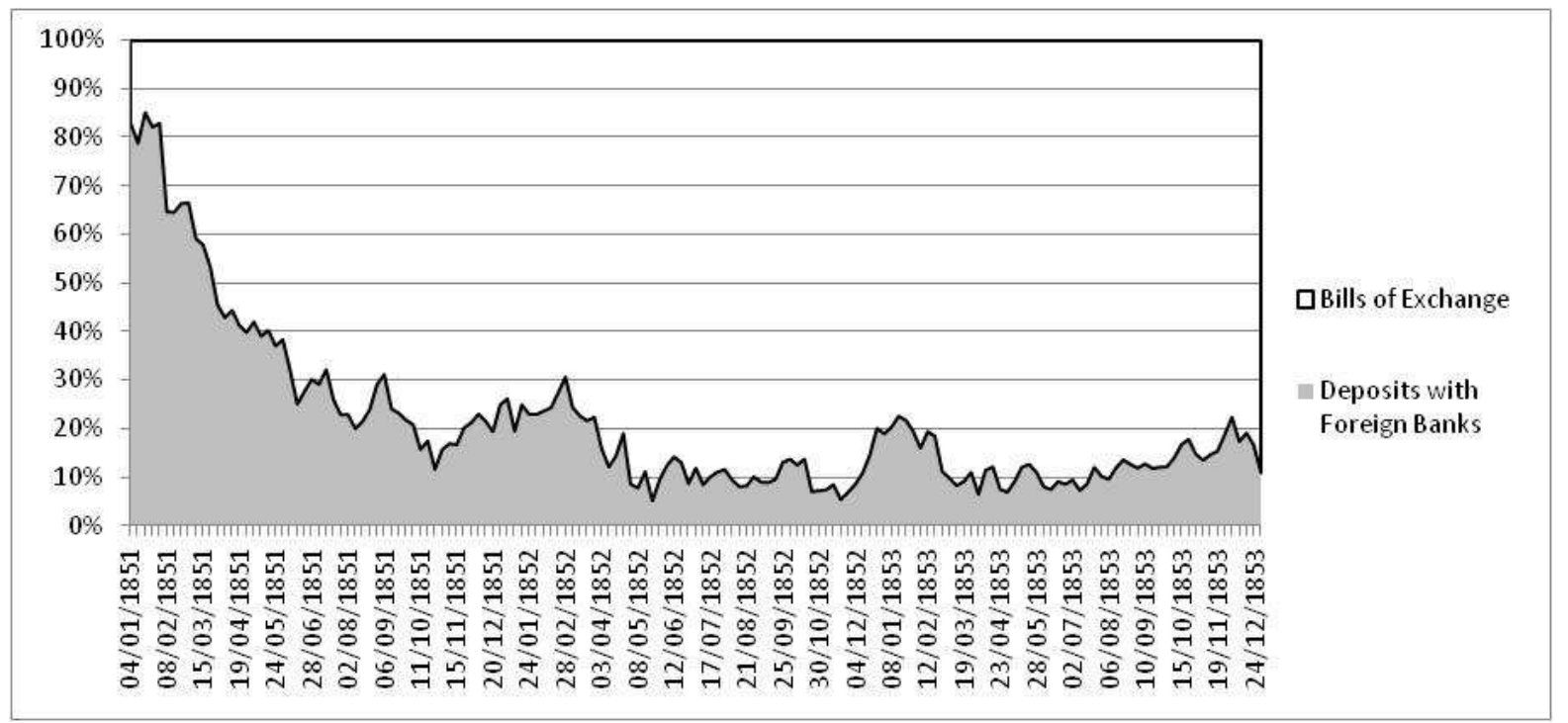

Source: author.

Figure 2: Composition of foreign reserves, 1851-3 (in Belgian francs)

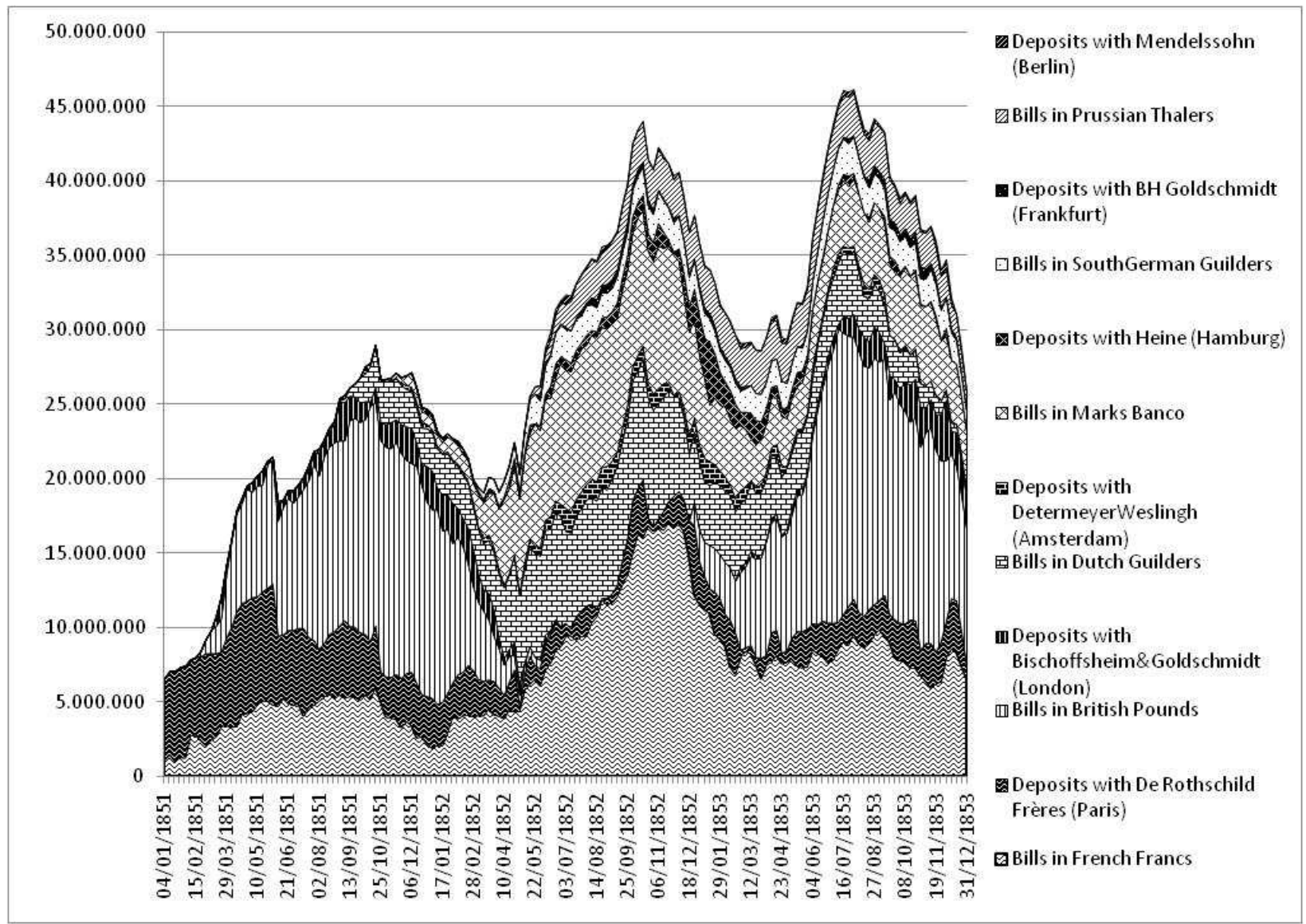

Source: author. 


\section{Purchasing and Dismissing Reserves: Strategies}

The previous paragraph has looked at the choice between bills and deposits as instruments for placing a given amount of a foreign currency. But which techniques did the NBB implement in order to modify the size or the currency composition of its foreign portfolio ${ }^{26}$ As a matter of fact, a variety of choices were available to the Bank in order to buy or sell a given currency, depending on the place on which it wished to operate:

- First, the Bank could operate on the onshore market of the currency (say, London for sterling). Here, local currency could be exchanged against bullion (1a), against bills in Belgian francs (1b), against bills in third currencies (say, French francs; 1c), or against claims on foreign banks (say, a transfer on a Paris house; 1d).

- Second, the Bank could operate on the offshore market for that currency in Belgium (say, the Antwerp market for sterling). Here, the given foreign currency could be exchanged against Belgian francs at the bourse and at the NBB counters (2a) $;{ }^{27}$ in alternative, the conversion could be implemented through direct transactions with Belgian banks (2b) or the Treasury (2c).

- Third, the Bank could operate on a third offshore market for that currency (say, the Paris market for sterling). Here, the given currency (sterling) could be exchanged against local currency (French francs) either in the form of bills (3a) or in the form of claims on local banks (3b).

\footnotetext{
${ }^{26}$ All operations not implying any modification in the portfolio (viz. mere renewals of bills of exchange coming to maturity) are not taken into account here. This explains why the general totals in table 1 and those in tables 3 and 4 do differ.

${ }^{27}$ Open-window discounts of foreign bills were presented by the NBB as a service offered to the Belgian public, but could be discontinued at any time: as a result, they were more similar to open-market operations than to standing facilities: Ugolini, S. (2011a, 2011b).
} 
Table 1: Total amount of operations implying a modification in the composition (grey) or in the size and composition (white) of the foreign portfolio, 1851-3 (in million Belgian francs)

\begin{tabular}{|c|c|c|c|}
\hline & & $\begin{array}{c}\text { Purchases of } \\
\text { Foreign } \\
\text { Assets }\end{array}$ & $\begin{array}{c}\text { Sales of } \\
\text { Foreign } \\
\text { Assets }\end{array}$ \\
\hline \multirow{4}{*}{$\begin{array}{c}\text { 1) on Their } \\
\text { Onshore Market } \\
\text { (with Foreign Banks) }\end{array}$} & 1a) against Bullion & 17.4 & 19.8 \\
\hline & 1b) against Bills in Belgian Francs & - & 10.7 \\
\hline & 1c) against Bills in Third Currencies & 3.5 & 37.9 \\
\hline & 1d) against Claims on Foreign Banks & - & 4.2 \\
\hline \multirow{3}{*}{$\begin{array}{l}\text { 2) on the Offshore } \\
\text { Market in Belgium } \\
\text { (against Belgian Francs) }\end{array}$} & 2a) with the General Public & 82.2 & 5.3 \\
\hline & 2b) with Belgian Banks & 12.8 & 38.4 \\
\hline & 2c) with the Treasury & - & 14.1 \\
\hline \multirow{2}{*}{$\begin{array}{c}\text { 3) on Third } \\
\text { Offshore Markets } \\
\text { (with Foreign Banks) }\end{array}$} & 3a) against Bills in Third Currencies & 37.9 & 3.5 \\
\hline & 3b) against Claims on Foreign Banks & 4.2 & \\
\hline \multicolumn{2}{|l|}{ TOTAL } & 158.0 & 133.9 \\
\hline
\end{tabular}

Source: author.

Of course, not all operations had the same effects on reserves: operations involving bullion or Belgian francs (1a, 1b, 2a, 2b, 2c) implied a change in the composition and size of the portfolio, while swaps of foreign currencies (1c, 1d, 3a, 3b) entailed a change in its composition only. Table 1 gives the total amounts transacted for each class of operations in $1851-3 .{ }^{28}$ The data show that increasing and decreasing reserves were not symmetric operations. When the NBB wished to acquire foreign assets, it most often resorted to the Belgian offshore market ( $52 \%$ of total purchases for operation $2 \mathrm{a}, 8 \%$ for $2 \mathrm{c}$ ) or to other offshore markets (38\% for 3a); rather surprisingly, the Bank seldom purchased new

\footnotetext{
${ }^{28}$ Swaps of foreign currencies are highlighted in grey. The amounts purchased and sold through swaps are obviously equal.
} 
currencies on their own onshore market - and when it did so, it mainly employed bullion (11\% for 1a). The picture was quite different in case the NBB wished to dismiss foreign assets. The Belgian offshore market still played an important role, but different agents were most often involved (mainly domestic banks: $29 \%$ of total sales for operation $2 b$, and the Treasury: $10 \%$ for $2 \mathrm{c}$ ), ${ }^{29}$ while the general public was seldom concerned (only $4 \%$ for $2 \mathrm{a}$ ). The onshore market of the given currency was now the main playground of operation (28\% for $1 \mathrm{c}, 15 \%$ for $1 \mathrm{a}$, and $8 \%$ for $1 \mathrm{~b}$ ), while third offshore markets were almost neglected (only $2 \%$ for $3 a)$.

The NBB's asymmetric behaviour in the reshuffling of its foreign portfolio provides insights on both market structure and policy aims. First, it suggests that on mid-19 ${ }^{\text {th }}$-century offshore foreign exchange markets, transaction costs (mainly connected with the bills' encashment procedures) were spread unevenly along the maturity curve: as the Bank purchased securities of longer maturity than the ones it sold, it was apparently cheaper for it to operate in offshore markets when it bought long bills than when it sold short ones. Second, it conveys the idea that offshore markets for the Belgian franc outside Belgium (on which the Bank almost never operated) were far less liquid than offshore markets for other currencies in Belgium: this can be interpreted as evidence of the juniority of the franc with respect to the main international currencies in the early $1850 \mathrm{~s} .{ }^{30}$ Third, it points to the fact that bank transfers (that the NBB seldom used) were still fairly unpractical means of payments with respect to exchange-traded bills. Finally, it confirms that the bulk of the Bank's operations were not dictated by monetary policy aims: the most systemically important kind of transaction, i.e. the purchase of bullion abroad (1a), barely represented $15 \%$ of total reserve dismissals. $^{31}$

\section{Credit Risk}

The previous paragraph has illustrated the techniques available to the NBB in order to modify the composition of its foreign portfolio. But what about the motives for diversification? The currency composition of the Bank's reserves was very volatile because it was almost exclusively driven by profitability concerns. ${ }^{32}$ This suggests that financial risk was dealt with in a rather easy way by the Bank. The previous section argued that liquidity

\footnotetext{
${ }^{29}$ The Treasury, to which the NBB acted as general cashier, regularly had to transfer money to De Rothschild Frères in Paris in order to pay for the coupons of Belgian sovereign bonds. This was performed through a repurchase of the Bank's claims on the Rothschild house.

${ }^{30}$ Flandreau, M. \& Jobst, C. (2005)

${ }^{31}$ Ugolini, S. (2011a)

${ }^{32}$ Ugolini, S. (2011a). The only exception was the reserve of French francs, which was never left to sink beneath a certain level (see below).
} 
risk associated with bills of exchange was kept low by their role as staple international means of payment, and that credit risk was moderated by the multiple-guarantee system. Still, how did such system work in practice?

While the amounts of foreign bills to be purchased were set by the Administration Board, the screening of the securities entering the NBB's portfolio had to be made by the bodies forming the Bank's own network. In case the foreign bill was discounted at one of the NBB's counters in Belgium, the security was always endorsed by one of the Bank's usual customers and thus bore his guarantee: as a result, the risk on these bills was governed by the same rules concerning the purchase of domestic bills. ${ }^{33}$ In case the foreign bill was discounted abroad by a correspondent, though, the problem was different: as a matter of fact, the Bank had to delegate completely the screening of 'signatures' to external agents located abroad. To solve this problem, all correspondents were asked to endorse themselves the bills they remitted to Brussels - i.e. to guarantee the Bank against possible defaults by the acceptors of the bills. ${ }^{34}$ As a result, credit risk associated with foreign bills was almost non-existent, except in case of a default by a correspondent. As the latter case would more properly figure under the heading of operational risk, it will be dealt with in the next section.

\section{Market Risk and the International Monetary System}

According to what has been said so far, only market risk was a real matter of concern within the Bank's foreign reserve management. Because of the self-liquidating nature of bills (which were automatically turned into cash at maturity), market risk mainly resulted from exchange rate volatility (i.e. currency risk). ${ }^{35}$

The six foreign currencies in which the NBB used to operate were all convertible into bullion: most of them, like the Belgian franc, into silver - except the British pound (which was convertible into gold) and the French franc (into silver or gold). Conversely, investing in inconvertible currencies was never considered as a viable option by the Bank. ${ }^{36}$ As a result, currency risk was determined by the credibility of convertibility commitments and the

\footnotetext{
${ }^{33}$ Kauch, P. (1950), pp. 92-9

${ }^{34}$ PV CdA, $8^{\text {th }}$ March $1851,12^{\text {th }}$ August $1851,2^{\text {nd }}$ March $1852,13^{\text {th }}$ April $1852,6^{\text {th }}$ May $1852,30^{\text {th }}$ October 1852.

${ }^{35}$ In reality, interest rate risk (i.e. the risk of selling a bill at a higher discount margin than the one at which it had previously been purchased) was also a component of market risk associated with bills. However, as the NBB seldom adopted an active diversification policy (generally keeping bills in portfolio until maturity), interest rate risk was junior to currency risk.

${ }^{36}$ Despite the non-negligible financial connections existing between Belgium and Austria (the exchange rate on Vienna was regularly quoted in Antwerp), the NBB refused to hold assets denominated in this important European currency because it was unconvertible. Nonetheless, the Bank occasionally happened to accept bills on Vienna, Milan, and Venice as collateral for repurchase agreements denominated in other currencies (PV CdA, $27^{\text {th }}$ February $1851,14^{\text {th }}$ and $30^{\text {th }}$ August 1851). That is why the Austrian currency area is included in figure 3.
} 
stability of the international monetary system. Because the latter proved remarkable in the 1850s notwithstanding a number of exogenous shocks, ${ }^{37}$ the Bank had the chance to modify aggressively portfolio composition without increasing considerably the exposition to financial risk.

Some considerations about the coeval international monetary system are in order. To be able to diversify its reserves, the Bank established a network of corresponding banks in the main financial centres of each currency area. Because it was the correspondents' task to take care of the encashment of maturing bills, from the Bank's viewpoint foreign securities were always payable in one of these six centres - where correspondents would turn them into cash. Yet this does not mean that all the bills in the NBB's portfolio were accepted by merchant banks established in these six cities: provided that they were denominated in the desired currency, bills could well be payable on other places. The fact that the NBB systematically kept record of where its bills were payable (IC 1851-3) allows to reconstruct the monetary geography of the $1850 \mathrm{~s}$ - a period in which the making of 'territorial money' was still an ongoing process. ${ }^{38}$ This is done in figure 3 , where the names of the financial centres quoted by NBB sources are reported. Three interesting features emerge from the picture. First, the Latin Monetary Union was a matter of fact long before the 1865 Convention officially established it: despite the fact that the uniformity of specie circulation within the franc area was disintegrating in the early $1850 \mathrm{~s},{ }^{39}$ Paris apparently remained the main money market for the whole region. ${ }^{40}$ Second, albeit the amount of thaler-denominated bills bought by the NBB was small (see figure 2), their geographical origin was remarkably diversified: this conveys the idea that Berlin was still a relatively underdeveloped money market in the 1850s, and that its later primacy over other German centres was a consequence of the Unification. ${ }^{41}$ Third, notwithstanding the fact that the mark banco was the official unit of account of the Free City of Hamburg only, mark-denominated bills were accepted by merchant banks located in other countries too (i.e. in Altona, Copenhagen, and Christiania): this suggests that at least the export-oriented portion of the Scandinavian banking systems was keeping its books in foreign instead of local currency - a phenomenon analogous to nowadays' dollarization. ${ }^{42}$

\footnotetext{
${ }^{37}$ Ugolini, S. (2010)

${ }^{38}$ Helleiner, E. (2003)

${ }^{39}$ Parker Willis, H. (1901)

${ }^{40}$ This is confirmed by the fact that all purchases of Belgian francs implemented by the NBB outside Belgium (i.e. operation $1 \mathrm{~b}$ in table 1 ) were actually performed in Paris - which means that the city hosted the only liquid offshore market for the Belgian franc.

${ }^{41}$ Cassis, Y. (2006)

${ }^{42}$ This is also reflected by the fact that the Swedish Riksbank reacted to the 1857 crisis by originating markdenominated bills: Ögren, A. (2007).
} 
Figure 3: Monetary geography in the 1850s, as emerging from the NBB's bill portfolio management. Seven main currency areas are highlighted: 1) franc (main financial centre: Paris), 2) sterling (London), 3) Dutch guilder (Amsterdam), 4) mark banco (Hamburg), 5) South-German guilder (Frankfurt), 6) thaler (Berlin), 7) Austrian guilder (Vienna)

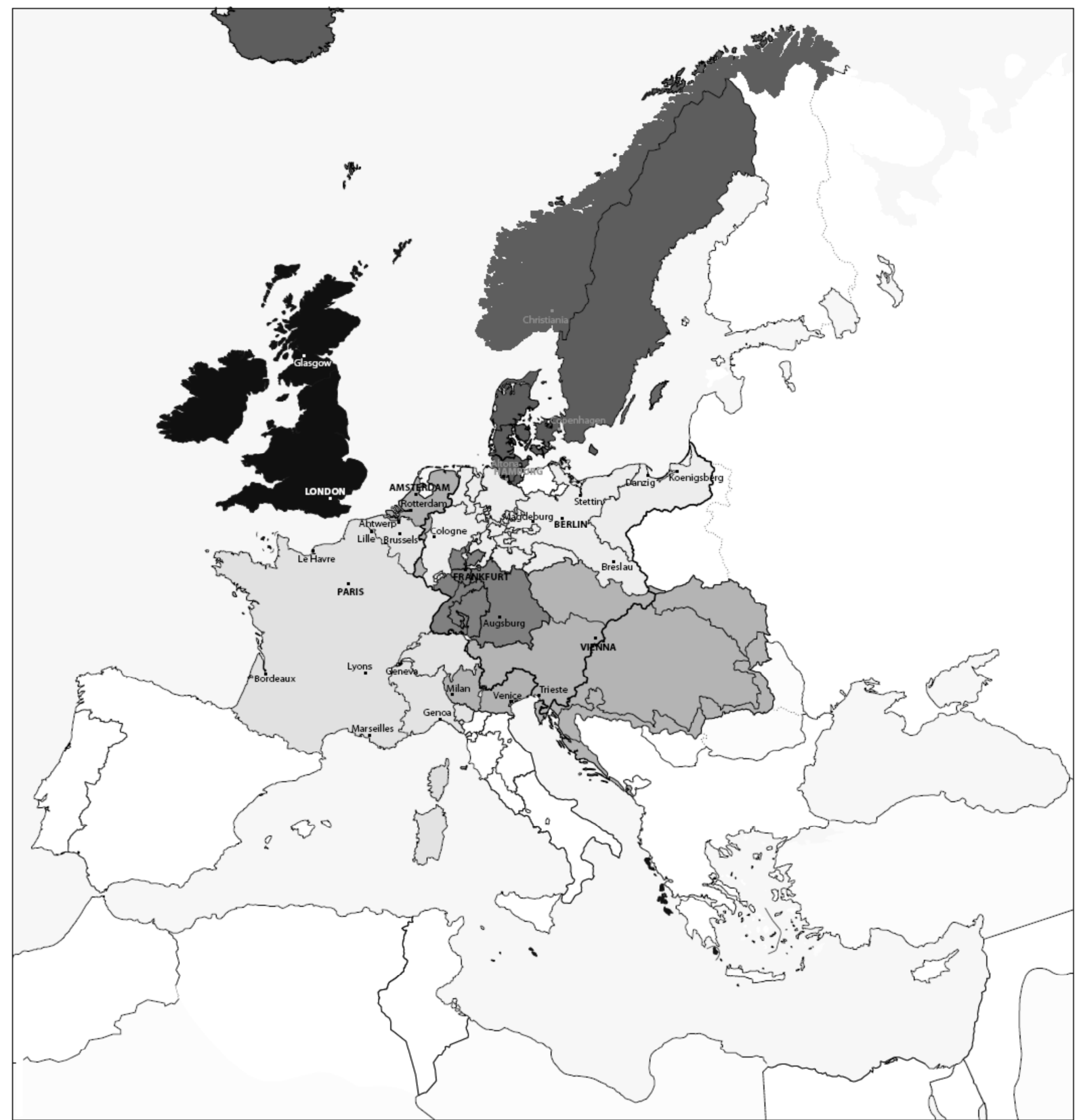

Source: IC 1851-3, and Lemale, A. (1875).

\section{Profitability}

The previous paragraph has argued that financial risk associated with foreign bills only depended on market (read, currency) risk, which was rather low in the 1850s despite the turbulent character of that decade. ${ }^{43}$ The way for testing this claim consists of looking at expost profitability. It is a particularly unfortunate circumstance that, by systematically merging

${ }^{43}$ Ugolini, S. (2010) 
domestic and foreign assets, the NBB's books do not allow for a precise assessment of the profitability of foreign reserves. Nonetheless, the annual reports to shareholders published by the Bank (RAG) contain a number of interesting elements, which are used in this paragraph in order to draw some conclusions.

Table 2: Gross profit of discount activities and loss on rediscount and exchange, 1851-3 (in thousand Belgian francs)

Source: RAG 1851-3.

\begin{tabular}{|l|r|r|r|}
\hline & \multicolumn{1}{|c|}{1851} & \multicolumn{1}{c|}{1852} & \multicolumn{1}{c|}{1853} \\
\hline Gross profit of discount activities & 823.6 & $1,496.2$ & $1,269.9$ \\
\hline Loss on rediscount and exchange & 136.0 & 113.3 & 178.1 \\
\hline $\boldsymbol{N E T}$ & $\mathbf{6 8 7 . 6}$ & $\mathbf{1 , 3 8 2 . 8}$ & $\mathbf{1 , 0 9 1 . 8}$ \\
\hline
\end{tabular}

The NBB was a profitable joint-stock company: the yearly return to capital for shareholders was equal to $7.25 \%$ in $1851,13.40 \%$ in 1852 , and $13.32 \%$ in 1853 . Discount activities contributed substantially to profit generation $(57.23 \%$ of total profits generated in $1851,52.67 \%$ in 1852 , and $64.45 \%$ in 1853$).{ }^{44}$ On the one hand, some elements on credit risk for discount activities are given by the amount of unpaid bills, which always equalled zero in 1851-3. On the other hand, some elements on market risk for discount activities are given by the losses made on rediscount and exchange (see table 2$):{ }^{45}$ as the NBB never resold on the open market the domestic bills it had previously discounted, the numbers only refer to foreign bills. It is possible to see that market risk had non-negligible effects in two turbulent years (1851 and 1853), yet much lower ones in a quiet year (1852). ${ }^{46}$ This depends on the fact that, in times of disturbances, the Bank could find itself bound to liquidate reserves regardless of eventual losses.

\footnotetext{
${ }^{44}$ These numbers include the remuneration of deposits by foreign correspondents - i.e. the other way than discount through which foreign reserves were made profitable.

45 'Losses on rediscount' consist of the difference between the discount margin at which the Bank had bought bills and the one at which it resold them on the market: these are losses associated with interest rate risk. 'Losses on exchange' consist of the difference between the exchange rate at which the Bank had bought bills and the one at which it resold them on the market: these are losses associated with currency risk.

${ }^{46}$ In 1853 (the only year for which details are available), losses from rediscount and exchange amounted to $21 \%$ of total gross profits from discount of foreign bills.
} 
Figure 4: Monthly gross product of discounting (in Belgian francs), 1853

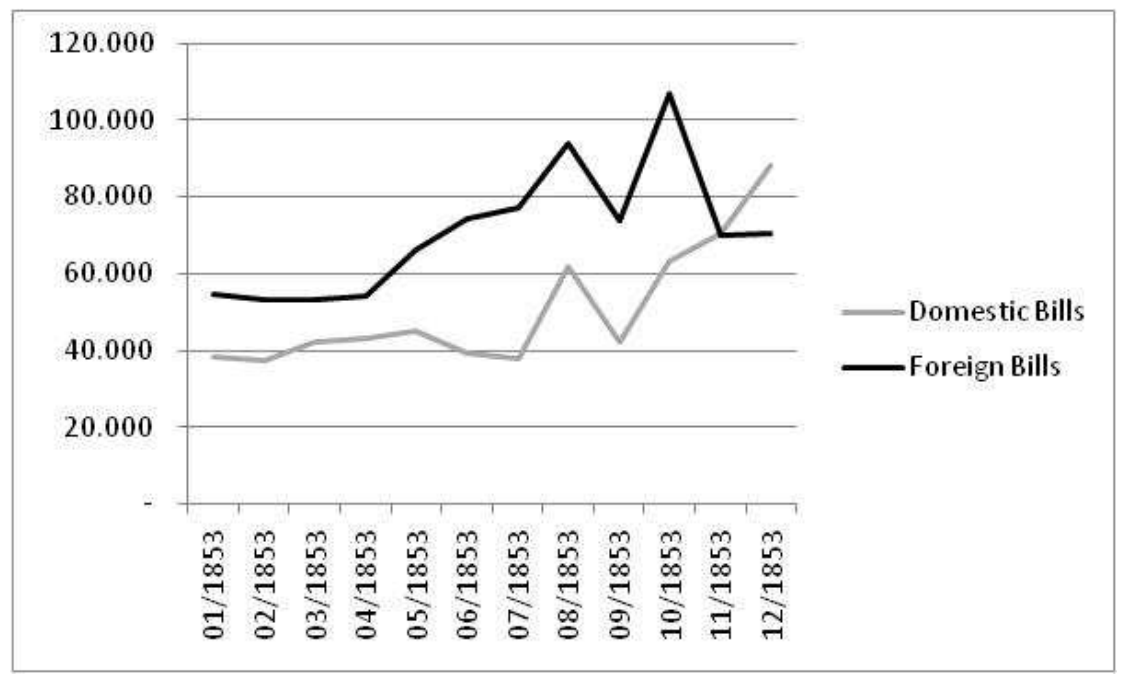

Source: RAG 1851-3.

Still, what was the actual contribution of foreign reserves to profit generation? On average, in 1851-3 the NBB's foreign bill portfolio was only slightly larger than the domestic bill portfolio. ${ }^{47}$ But were foreign exchange operations as profitable as domestic ones? RAG only provides some elements for the year 1853. Figure 4 shows that the gross product of discount for foreign bills was predominant during most of that year. For the same period, figure 5 compares the average gross profitability of discount operations on a currency basis. ${ }^{48}$ On the whole, foreign operations were generally (but not always) slightly more profitable than domestic ones. This confirms the impression that low financial risk was associated with these monetary instruments.

\footnotetext{
${ }^{47}$ Ugolini, S. (2011a)

${ }^{48}$ Note that numbers in figure 5 do not represent yields, as the maturity of bills discounted is unknown. The figure gives the ratio of gross profits from discount to the volumes discounted. Albeit not a yield, this is a significant indicator anyway. As the treatment of bills implied a number of fixed costs, it was preferable for the Bank to hold bills of longer maturity (although not exceeding ninety days). In the case of open-window discounts of domestic bills, that Bank could not choose the maturity of the securities it purchased: as a result, the average maturity of its domestic portfolio tended to be shorter than its foreign portfolio. All other things equal, this meant a lower profitability of domestic operations with respect to foreign ones. Shorter maturity of bills is reflected by a lower ratio of gross profits to the volume discounted - as shown by figure 5 .
} 
Figure 5: Monthly ratio of gross profits from discount to total volumes discounted per currency, 1853

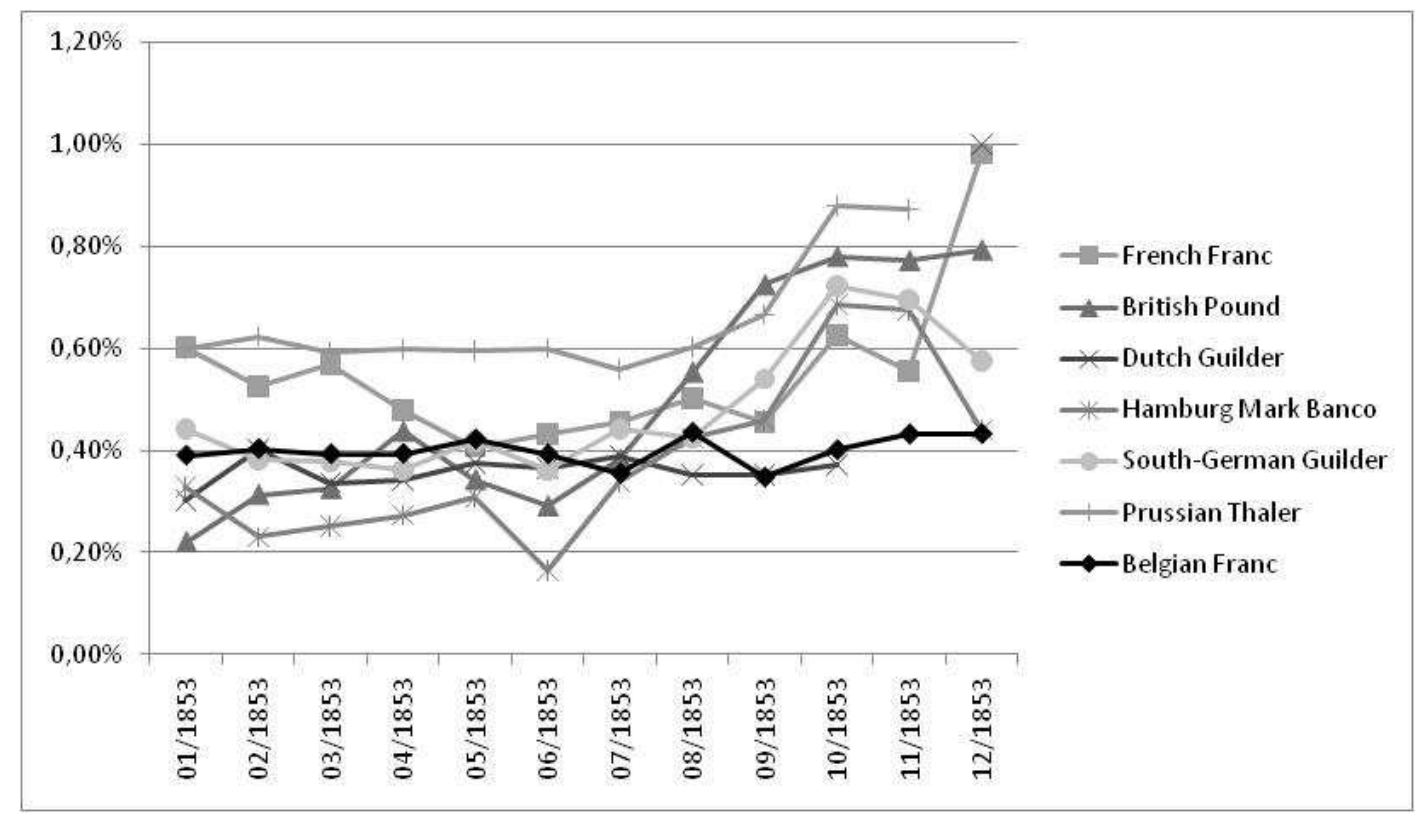

Source: RAG 1853.

\section{Financial Risk Management: Sum-Up}

The structure of financial risk associated with foreign bills of exchange was considerably different than the one associated with domestic bills. Liquidity risk was basically non-existent for foreign bills (which could be easily sold in the open market, backed by the rediscounting facilities of a foreign central bank), while it was a real concern for domestic ones (which could not be resold by the domestic central bank itself). Credit risk was also rather low for foreign bills (at least, as long as the guarantee supplied by correspondents was effective), while it was much higher for domestic bills (as shown by the losses the Bank would suffer from domestic defaults some years later). ${ }^{49}$ On the contrary, market risk was non-existent for domestic bills, while it was non-negligible for foreign ones: mainly originating from exchange rate volatility, this risk was nevertheless not much sizeable in a stable international fixed-exchange-rate regime. On the whole, it is possible to conclude that the nature of the $19^{\text {th }}$-century international monetary system and of the credit instruments associated with it allowed for the maintenance of a remarkably low amount of financial risk in foreign reserve management.

\footnotetext{
${ }^{49}$ Kauch, P. (1950), pp. 122-8
} 


\section{Operational Risk in $19^{\text {th }}$-Century Foreign Reserve Management: The Belgian Case}

The fact that the NBB did not suffer losses from insider practices on foreign reserves does not mean that the Bank was actually not exposed to operational risk during the period of our concern. The structure of decision-making related to foreign reserves assigned to the Administration Board the power to decide how many bills would be discounted by each member of the Bank's network, and to the correspondents the power to decide which bills would be discounted. As said, credit risk on foreign bills was non-existent only as long as the guarantee supplied by correspondents was not a matter of doubt. This means that the NBB was exposed to moral hazard with respect to its network. As a matter of fact, a misbehaving correspondent might have taken advantage of its role as delegated screener for selling to the Bank low-quality assets at the price of first-order ones. Worse than that, the correspondent was in the position to make the Bank discount speculative-grade bills originated by himself (by 'cross-firing' with colluding agents): in other words, instead of acting as a mere intermediary, the correspondent had the opportunity of using the NBB in order to refinance himself at a cheaper rate than the market rate. ${ }^{50}$ In view of this all, an accurate selection of the members of the network proved the keystone of the Bank's risk management. This choice was entirely delegated to the Administration Board: collusion between the Board and correspondents, therefore, would be conducive to agency problems. As a result, the way for assessing the Bank's exposition to operational risk consists of reviewing the selection procedure of external agents. In case the procedure were implemented in an unbiased way, one would expect the NBB to look for the intermediaries bearing the best reputation in each foreign place - viz., those for which the opportunity cost of misbehaving (i.e. losing reputation) was the highest. Was this actually always the case?

\section{Structure of the Network}

As said, the NBB needed to implement transactions in six European financial centres: in order to do this, a regular correspondent was chosen in each of these places. Regular correspondents were the ones with which the Bank also kept deposits. However, the NBB often happened to accomplish some occasional operations, in the same places where it had regular correspondents, through other agents. This means that regular correspondents did not hold a monopoly of financial intermediation (on the Bank's account) in their own place: the

\footnotetext{
${ }^{50}$ It was with the aim of detecting this kind of collusion that the Bank of England had put in place the sophisticated monitoring system described by Flandreau, M. \& Ugolini, S. (2011). However, the NBB was not in the position of cross-checking the signatures on bills remitted by its correspondents, and thus heavily depended on the rectitude of its correspondents.
} 
NBB could resort to competitors in order to be granted better conditions. No deposits were kept with these occasional correspondents: as no continuity existed, operations were financed one by one. For the reasons illustrated above, all foreign correspondents were chosen among merchant banks.

Table 3 gives the total amount of bills (including renewals) discounted by each component of the NBB's network in 1851-3. While discounting of foreign bills in Belgium constituted the most popular way for accumulating new reserves (see table 1), renewals of maturing bills abroad drove most of the volume of all discounting activities. The bulk of the business was conducted by regular correspondents, but occasional ones also played an important role. As correspondents were remunerated only on the basis of fees on discounting (encashment of maturing bills was made for free), a larger volume of discounts meant higher remuneration for the corresponding agent. While on some places the Bank only resorted to one single agent, on some others business was split to different competing houses - especially in the case of Paris, where the regular correspondent (De Rothschild Frères) only covered 70\% of total operations.

Table 3: Total purchases of foreign bills per correspondent, 1851-3 (in million Belgian francs)

\begin{tabular}{|l|r|r|}
\hline Antwerp & 34.7 & \\
\hline Brussels and Provinces & 47.5 & 82.2 \\
\hline Total NBB Counters & 78.3 & \\
\hline De Rothschild Frères (Paris) & 96.5 & \\
\hline Bischoffsheim \& Goldschmidt (London) & 38.3 & \\
\hline Determeyer Weslingh en Zoon (Amsterdam) & 48.7 & \\
\hline Salomon Heine (Hamburg) & 15.1 & \\
\hline Benedikt Hayum Goldschmidt (Frankfurt) & 25.1 & \\
\hline Mendelssohn-Bartholdy und Kompagnie (Berlin) & 14.6 & \\
\hline Total Regular Correspondents & 17.6 & \\
\hline Bischoffsheim, Goldschmidt et Cie (Paris) & 0.7 & \\
\hline Fould et Fould-Oppenheim (Paris) & 9.0 & \\
\hline Noël, Page et Cie (Paris) & 1.9 & \\
\hline Nathan Mayer Rothschild \& Sons (London) & 1.8 & \\
\hline Ludwig Raphael Bischoffsheim (Amsterdam) & & 45.6 \\
\hline Mayer Amschel von Rothschild und Söhne (Frankfurt) & & \\
\hline Total Occasional Correspondents & & \\
\hline TOTAL & & \\
\hline So: & & \\
\hline
\end{tabular}

Source: author. 


\section{Selection of Correspondents: Facts}

Table 3 allows to perform the test proposed at the beginning of this section. Together with long-established, first-order merchant banks (such as the Rothschild, Fould, Determeyer, Heine, or Mendelssohn houses), the list of the Bank's correspondents also included a number of less reputed agents - most notably the London, Paris, Amsterdam, and Frankfurt branches of the Bischoffsheim-Goldschmidt group. Except perhaps the Frankfurt one, the Bischoffsheim houses were recently established, relatively small, and with a rather bad reputation. ${ }^{51}$ Given that these agents were much more exposed to the temptation of misbehaving, why did the NBB put itself in a potentially dangerous position?

The members of the body in charge of the selection of correspondents (the Directors) had mostly been chosen among the former administrators of Banque de Belgique, a joint-stock commercial bank which held $60 \%$ of the NBB's capital. All Directors were local businessmen with a strictly domestic orientation, except one: the merchant banker Jonathan-Raphaël Bischoffsheim, head of the Brussels branch of the Bischoffsheim-Goldschmidt group. ${ }^{52}$ The minutes of the Board show that the choice of the Bank's correspondents produced tensions between the merchant banker (who tried to favour his own group) and the representatives of minority stakeholders (who pushed for the leading merchant banks of the time, and especially for the house of Rothschild). ${ }^{53}$

Because of its small size and poor reputation, the Bischoffsheim group was inadequate to supply the Bank with the whole range of services it needed. This was particularly clear in the case of Paris. In the event of crises, the NBB needed to import quickly from France huge amounts of silver coins in order to maintain convertibility ${ }^{54}$ in view of the crucial function it played, the Bank's correspondent in Paris had to be able to guarantee the immediate conversion of reserves into species. No bank could credibly commit to insure this large-scale supply except the house of Rothschild, the leading operator on international bullion markets -

\footnotetext{
${ }^{51}$ For instance, in 1854 the ratings book of the old house of Crommelin described the Amsterdam Bischoffsheim bank as 'entirely or largely broken': Posthumus, N. (1921), p. 202. Flandreau, M. \& Ugolini, S. (2011) show that as late as 1865, the London Bischoffsheim house borrowed heavily from the Bank of England in non-crisis time - a behaviour associated with second- rather than first-order banks. In the same year, the head of the Paris Bischoffsheim house pledged for a laxer screening policy by the Bank of France, which refused to discount bills bearing less than three signatures: he did that by stressing the easiness of finding bad-quality endorsers if needed - a business to which he was apparently familiar: Kindleberger, C. (1984), p. 230. In the 1870s, the London house would infamously emerge as the main issuer of junk sovereign bonds on the British market: see Report... on the Loans (1875).

${ }^{52}$ Kauch, P. (1950) pp. 84-9; Ugolini, S. (2011b)

${ }^{53}$ See e.g. PV CdA, $8^{\text {th }}$ March $1851,10^{\text {th }}$ June $1851,13^{\text {th }}$ and $25^{\text {th }}$ November $1851,30^{\text {th }}$ March $1852,13^{\text {th }}$ April 1852, etc.; also see Kauch, P. (1950), pp. 99-101.

${ }^{54}$ Ugolini, S. (2011a)
} 
as well as the monopolistic supplier of this kind of services to central banks. ${ }^{55}$ This explains why De Rothschild Frères was the only correspondent with which the NBB had large (and exceptionally, remunerated) deposits. As a result, competition with the Rothschild group on this field was clearly out of question for the Bischoffsheims.

What the Bischoffsheims could (and did) do, instead, was 'dumping' their competitors viz., offering slightly better prices for the purchase of foreign bills. This was easy, as the bankers operated on a different segment of the bill market than their competitors. As a matter of fact, bills were not uniform instruments: as the quality of each asset was determined by the signatures impressed on them (acceptor and endorsers), plenty of different discount rates (corresponding to each quality class) were in force at any moment on the bill market. ${ }^{56}$ Not being considered as first-order securities, bills bearing the Bischoffsheims' signature were discounted on the market at higher rates than those bearing the guarantee of more reputed houses. In normal conditions, the NBB would have abstained from purchasing second-order securities; but the presence of a family member on the Board did matter. Thanks to JonathanRaphaël's lobbying, the Bank was induced to consider the quality of Bischoffsheimguaranteed bills as high as (say) Rothschild-guaranteed ones. Given this, it was easy for the Bischoffsheims to discount on behalf of the Bank at a higher rate than the one offered by the Rothschilds without reducing their profit margins, because the rate proposed to the NBB was still lower than the rate at which the very same bills were discounted on the market. But not only were the Bischoffsheims able to make extra profits on intermediation; they also were in the position to refinance themselves at particularly advantageous conditions. By directly originating bills then resold to the NBB at a higher price than the market one, the group was given the chance of growing much more leveraged at relatively low cost.

Table 4: Total purchases of foreign bills per group of correspondents, 1851-3 (in million Belgian francs)

\begin{tabular}{|l|r|}
\hline NBB Counters & 82.2 \\
\hline Rothschild Group & 89.1 \\
\hline Bischoffsheim-Goldschmidt Group & 128.1 \\
\hline Other Foreign Correspondents & 130.4 \\
\hline TOTAL & $\mathbf{4 2 9 . 8}$ \\
\hline
\end{tabular}

Source: author.

Thanks to their access to insider information, the Bischoffsheim houses regularly

\footnotetext{
${ }^{55}$ Flandreau, M. (1997)

${ }^{56}$ This is always the case for interbank interest rates - as is, for instance, LIBOR today.
} 
approached the Board to offer more advantageous conditions than their competitors: in this way, they managed to secure a good portion of the Bank's business in Paris - and this, despite the fact that the Rothschilds had explicitly asked to be granted the monopoly of operation on that place. ${ }^{57}$ As shown by table 4 , the Bischoffsheim group finally managed to appropriate a large slice of the Bank's foreign business in 1851-3. The main contribution to this success came from Jonathan-Raphaël's ability to secure for his family the role of regular correspondents for the sterling area. Managing the NBB's large business, the newlyestablished Bischoffsheim-Goldschmidt house abruptly became an important player on the London discount market: this is illustrated by figure 6, where the volumes discounted on behalf of the NBB are compared with those discounted by the most important player of all (the Bank of England). By rapidly acquiring market power in the core financial centre of the time, and by acquiring the possibility of refinancing on a vast scale at cheaper rates than market ones, the group set the foundations for its emergence as a leading international actor which would eventually occur under the unified label of Paribas, the joint-stock bank merging the Bischoffsheims' concerns in the 1870s. ${ }^{58}$

\footnotetext{
${ }^{57} \mathrm{PV}$ CdA, $6^{\text {th }}$ March 1852.

${ }^{58}$ Bussière, E. (1992)
} 
Figure 6: Weekly amounts discounted by Bischoffsheim \& Goldschmidt on behalf of the NBB on the London market, compared with the amounts discounted by the Bank of England (in British pounds), 1851-3

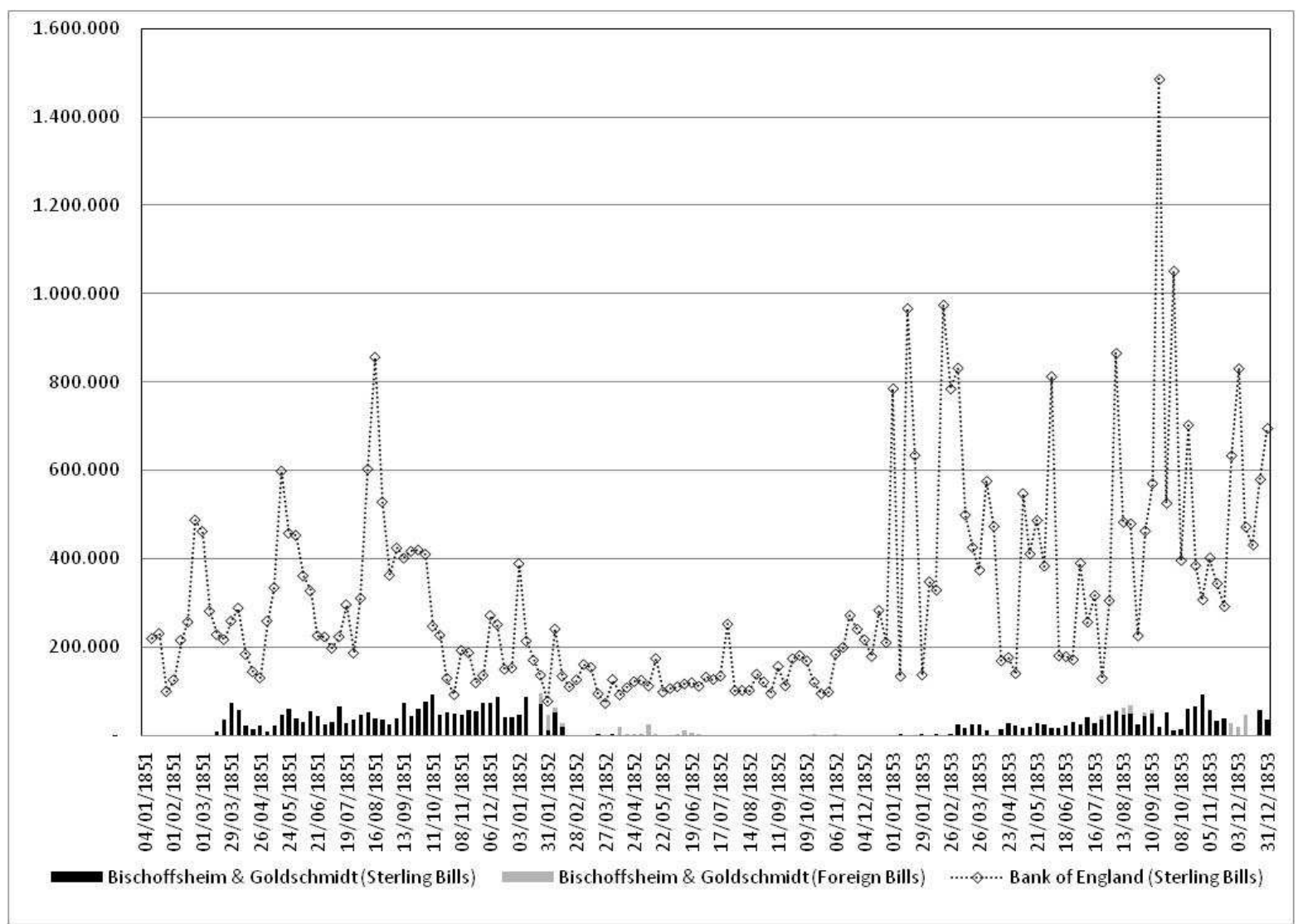

Sources: author, and BoE C28/11-3.

\section{Operational Risk Management: Concluding Remarks}

The NBB's foreign reserve management practices opened scope for patent conflicts of interests to occur: the personal links between insiders and correspondents exposed the Bank to agency problems. Although the overall success of the Bischoffsheim group (thereafter Paribas) gradually increased the opportunity cost (and hence decreased the probability) of misbehaving, the NBB would have certainly suffered significant losses in case the Bischoffsheims' screening practices and guarantees had proven to be dubious. But there is more: echoing coeval criticism (see e.g. RAG 1856), one may wonder if the incentive structure embedded in such conflicts of interests was not pushing the Bank towards an excessive foreign discount activity. The question may be reformulated as follows: was the level of cash surplus targeted by the Board fully appropriate, or was it set too low due to a bias towards accumulating foreign reserves? ${ }^{59}$ Although the issue is impossible to settle, the question is nonetheless legitimate. As most $19^{\text {th }}$-century central banks had international merchant bankers sitting in their boards, the agency problem highlighted by the NBB's

\footnotetext{
${ }^{59}$ Ugolini, S. (2011a)
} 
foreign reserve management practices must not have been an isolated case. The need to bypass the dependence from merchant bankers' informational networks might have encouraged the development of in-house expertise on foreign exchange markets towards the end of the century. ${ }^{60}$

\section{Conclusions}

Through a case study on 1850 s Belgium, this chapter has looked at $19^{\text {th }}$-century foreign exchange reserve management from the perspective of current issues. Two main findings have emerged.

On the one hand, a number of circumstances used to make financial risk associated with reserves particularly low in the past. At a time in which deposits were rather unpractical and bonds still fairly illiquid, bills of exchange proved the ideal instrument to combine liquidity and profitability targets. Basically no liquidity risk was associated with these securities, while credit risk was limited by the mutual guarantee system; as a result, only a small amount of market risk remained, mostly tied to exchange rate fluctuations - in turn, limited by the operation of credible fixed-exchange-rate regimes.

On the other hand, operational risk associated with reserve management used to be potentially high: the structure of decision-making allowed for the presence of patent conflicts of interests, which exposed central banks to agency problems. This structure also engendered perverse incentives to increase foreign exchange activities because of the profit-seeking attitude of insiders colluding with correspondents.

These findings highlight the big differences existing between then and now: nowadays, operational risk is limited by sophisticated reporting techniques, while financial risk is kept much higher by the current architecture of the international financial system. An assessment of the pros and cons of each system is far from straightforward. As far as we know, the apparent underestimation of operational risk by $19^{\text {th }}$-century central bankers does not seem to have generated major losses. On the contrary, the recent crisis seems to show that nowadays' financial architecture has made all kinds of financial risks associated with reserve management (market, credit, and liquidity risk) conducive to potentially large losses for central banks. This calls for further reflections on the way foreign exchange reserve management should or should not evolve in the future.

\footnotetext{
60 This seems to have been the case, for instance, at the Austro-Hungarian National Bank, where the centralization of foreign exchange operations to a specially-appointed body in the 1890s was coupled with the relaxation of the traditional links with merchant bankers: Jobst, C. (2007).
} 


\section{Archival Sources}

Archives Générales du Royaume/Algemeen Rijksarchief (Brussels), Fonds Banque Nationale:

- PV CdA: Procès-verbaux du Conseil d'Administration (Minutes of the Board of Directors), 1850-9.

- IC: Indicateur de la correspondance $d u$ Gouverneur (Index of the Governor's correspondance), 1851-3.

Banque Nationale de Belgique/Nationale Bank van België (Brussels), Archives Centrales/Centraal Archief:

- RAG: Rapports du Gouverneur à l'Assemblée Générale des actionnaires (Annual Reports to Shareholders), 1851-3; 1856.

Bank of England Archive (London), Cashiers' Department:

C28/11-3: Daily Discounts, 1851-3.

\section{References}

Accominotti, O. (2010) Foreign Exchange Reserves, Financial Instability and Contagion: Three Essays on the Great Depression PhD diss. Sciences Po Paris.

Accominotti, O. (2011) "London Merchant Banks, the Central European Panic and the Sterling Crisis of 1931" Mimeo.

Battilossi, S. (2000) "Financial Innovation and the Golden Ages of International Banking: 1890-1931 and 1958-81” Financial History Review 7 pp. 141-175.

Borio, C., Ebbesen, J., Galati, G. \& Heath, A. (2008a) "Foreign Exchange Reserve Management: Elements of a Framework" BIS Paper 38.

Borio, C., Galati, G. \& Heath, A. (2008b) "Foreign Exchange Reserve Management: Trends and Challenges" BIS Paper 40.

Bussière, E. (1992) Paribas, 1872-1992: l'Europe et le monde Fonds Mercator.

Cassis, Y. (2006), Capitals of Capital: A History of International Financial Centres, 17802005 Cambridge University Press.

Chapman, S. (1984) The Rise of Merchant Banking Routledge.

Courcelle-Seneuil, J.-G. (1857) Traité théorique et pratique des opérations de banque $3^{\text {rd }}$ ed. Guillaumin.

De Cecco, M. (1974) Money and Empire: The International Gold Standard Blackwell.

Eichengreen, B. \& Flandreau, M. (2009), "The Rise and Fall of the Dollar (or When Did the Dollar Replace Sterling as the Leading Reserve Currency?)" European Review of Economic History 13:3 pp. 377-411.

Flandreau, M. (1997) "Central Bank Cooperation in Historical Perspective: A Sceptical View” Economic History Review 50:4 pp. 735-763. 
Flandreau, M. \& Gallice, F. (2005) "London, Paris, and the International Money Market: Lessons from Paribas, 1885-1913" in Bussière, E. \& Cassis, Y. (eds.) London and Paris as International Financial Centres in the Twentieth Century Oxford University Press pp. 78-106.

Flandreau, M. \& Jobst, C. (2005) "The Ties that Divide: A Network Analysis of the International Monetary System, 1890-1910” Journal of Economic History 65:4 pp. 977-1007.

Flandreau, M. \& Ugolini, S. (2011) "Where It All Began: Lending of Last Resort and the Bank of England during the Overend-Gurney Panic of 1866", in Bordo, M. \& Roberds, W. (eds.) A Return to Jekyll Island: The Origins, History, and Future of the Federal Reserve forthcoming Cambridge University Press.

Goschen, G. (1864) The Theory of the Foreign Exchanges $4^{\text {th }}$ ed. Effingham Wilson.

Helleiner, E. (2003) The Making of National Money: Territorial Currencies in Historical Perspective Cornell University Press.

Jobst, C. (2007) Trois études en histoire bancaire et financière au XIXe siècle $\mathrm{PhD}$ diss. Sciences Po Paris.

Kauch, P. (1950) La Banque Nationale de Belgique, 1850-1918 BNB.

Kindleberger, C. (1984) A Financial History of Western Europe $1^{\text {st }}$ ed. Allen \& Unwin.

Lemale, A. (1875) Monnaies, poids, mesures et usages commerciaux de tous les états du monde $2^{\text {nd }}$ ed. Hachette.

Ögren, A. (2007) "Lender of Last Resort in a Peripheral Economy with a Fixed Exchange Rate: Financial Crises and Monetary Policy in Sweden under the Silver and Gold Standards, 1834-1913" in Cottrell, P., Lange, E. \& Olsson, U. (eds.) Centres and Peripheries in Banking: The Historical Development of Financial Markets Ashgate pp. 223-252.

Øksendal, L. (2008) "Monetary Policy under the Gold Standard: Examining the Case of Norway, 1893-1914” Norges Bank Working Paper 2008/14.

Parker Willis, H. (1901) A History of the Latin Monetary Union: A Study of International Monetary Action University of Chicago Press.

Pihlman, J., \& van der Hoorn, H. (2010) "Procyclicality in Central Bank Reserve Management: Evidence from the Crisis" IMF Working Paper 2010/150.

Posthumus, N. (1921) "Nota over den toestand van de Amsterdamsche handelshuizen in het jaar 1854” Economisch-Historisch Jaarboek 7 pp. 196-209.

Reis, J. (2007) “An 'Art', Not a 'Science'? Central Bank Management in Portugal under the Gold Standard 1863-1887” Economic History Review 60:4 pp. 712-741.

Report from the Select Committee on Loans to Foreign States; together with the Proceedings of the Committee Minutes of Evidence, Appendix, and Index British Parliamentary Papers 1875 (367).

Schnabel, I. \& Shin, H. (2004) "Liquidity and Contagion: The Crisis of 1763" Journal of the 
European Economic Association 2:6 pp. 929-968.

Suzuki, T. (1994) Japanese Government Loan Issues on the London Capital Market, 18701913 Athlone Press.

Ugolini, S. (2010) “The International Monetary System 1844-1870: Arbitrage, Efficiency, Liquidity" Norges Bank Working Paper 2010/22.

Ugolini, S. (2011a) "The Origins of Foreign Exchange Policy: The National Bank of Belgium and the Quest for Monetary Independence in the 1850s" forthcoming European Review of Economic History.

Ugolini, S. (2011b) “An 'Atypical' Case? The First Emergence of Brussels as an International Financial Centre, 1830-1860", in Cassis, Y. \& Quennouëlle-Corre, L. (eds.), Institutions, Markets, and Capital Flows from the 1880s to the Present: Why Are Financial Centres Attractive? forthcoming Oxford University Press. 